\title{
Nigeria: \\ Perceptions of Disarmament, Demobilisation and Reintegration Modelling. Challenges and Prospects for Peace in Niger Delta
}

\author{
James OKOLIE-OSEMENE
}

\begin{abstract}
Disarmament, demobilisation and reintegration (DDR) is a mechanism that mitigates the outbreak of violence. It has three components critical for peace, reconstruction and stability in every post-conflict society. The DDR programme commenced in 2009, when restive youths agitating for resource control accepted the amnesty proclaimed by President Umaru Yar'Adua. With primary and secondary data, the study investigated the perceptions communities have of the DDR for ex-militants, as well as the challenges and prospects for peace in the Niger Delta. The study showed that most of the respondents established a link between militancy and unemployment. The ex-militants were at peace with their various communities. The majority (76.5\%) of the respondents believed that such ex-militants pose no threat to their communities after their being re-integrated. A major hindrance to the DDR is the unwillingness of some groups to totally disarm, while excluded groups agitate over exclusion in the programme. This contributed to the resurgence of youth violence against oil companies and security operatives in the Niger Delta. Therefore, preventing the resurgence of youth restiveness demands timely management of the conflicts that are motivated by grievances and lack of equity in the distribution of resources.
\end{abstract}

Keywords: Amnesty, DDR, Federal Government, militancy, perceptions, Niger Delta.

\section{Introduction}

Most parts of the world have become enclaves of armed conflicts and insecurity, which are usually caused by new security threats or rapid increase in criminality (Ashkenazi, 2013; Hove, Ngwerume, \& Muchemwa, 2013; Donais, 2017; Nwobueze \& Okolie-Osemene, 2017; Okolie-Osemene \& Okolie-Osemene, 2017; Danjibo \& OkolieOsemene, 2018). This emerging trend has
James OKOLIE-OSEMENE

Department of International Relations

Wellspring University, Nigeria

E-mail: okolieosemenej@gmail.com

Conflict Studies Quarterly

Issue 24, July 2018, pp. 26-43

DOI:10.24193/csq.24.3

Published First Online: 05/07/2018 
implications for the position of states on the Global Peace Index (GPI), which maps the most peaceful and most dangerous places in the world. Security provision in many cities across the developing world is fluid, involving complex and hybrid arrangements by numerous state and non-state actors (Gupte, 2017). Disarmament, demobilisation and reintegration (DDR) are the responsibilities of state security providers that aim to offer outlaw security providers the opportunity to shun violence. It is crucial that state security providers address the problem of militancy because armed groups have a propensity to fuel the activities of insurgency (Guéret, 2017).

For over a decade, the Niger Delta militants represented the biggest security threat to the government and people in the region. Different militant groups, such as Movement for the Emancipation of the Niger Delta (MEND), the Supreme Egbesu Assembly (SEA), and the Reformed Niger Delta Peoples Volunteer Force (NDPVF), with various degrees of alliance, were able to initiate attacks and strike targets in the region. Most of the attacks directly or indirectly affected oil exploration. The conflict escalated to a level that made it attract the attention of the international community and threaten the multinational oil companies operating in the area.

Militancy in the Niger Delta is traceable to the emergence of oil industry, oil prospecting, exploration and exploitation and, later, oil boom, which some people in oil-bearing communities believe has not transformed the region in terms of economic and infrastructural development. The scope of this study covers the disarmament, demobilisation and reintegration (DDR) programme in the Niger Delta region from 2009, when amnesty was proclaimed, to 2018. The study puts in proper historical context the activities of armed gangs.

Apart from environmental degradation, other factors that motivate people to protest are lack of access to basic necessities of life, such as water, shelter, health facilities, food and clothing, as well as rising unemployment, which led to sudden proliferation of militant groups. Apart from the inability of the oil companies to address most compensation problems and the needs of the communities in accordance with corporate social responsibility (Odera, Scott, \& Gow, 2018), the people felt betrayed by successive governments through neglect of their well-being and security. This made them resort to violence to seek redress.

Musari (2012, p. 3) asserts that:

In the wake of the creation of the Niger Delta Ministry, hopes were high; there were high expectations from a people who were grateful for government's attention. They were sure that in few years, the Niger Delta region would be transformed with the various projects that would make life easy for the old and as well, ensure that youths were gainfully engaged and their future secured. Sadly, these hopes and expectations are far from reality three years after and 
with the situation on ground, the region is far from seeing its expectations transform into real development.

It is often believed that the establishment of both the Niger Delta Development Commission (NDDC) and the Ministry of Niger Delta Affairs did not contain youth restiveness in the Niger Delta especially militancy and oil theft. January 2009 was described as the peak of youth restiveness or militancy in the Niger Delta. Nwafor (2011,p.189) explains that "the government led by late President Yar'Adua believed that the benefits of negotiating with militants in the Niger Delta far outweighed the chances of winning the conflict by force of arms. If for nothing else, the President was so articulate to realise the risk of making Niger Delta a theatre of war." From this, we can say that the government realised that short-term peace through Joint Military Task Force (negative peace) in the Niger Delta would not provide the needed sustainable peace, as it would not address the lingering agitations and festering crisis.

This article set out to:

- investigate the perceptions of people in Niger Delta communities of the reintegration of ex-militants in their communities;

- examine the key challenges facing successful reintegration of ex-militants;

- discuss the prospects of the DDR programme in oil producing communities.

\section{Significance of the Study}

Most studies on amnesty programme have not established a link between perceptions and the disarmament, demobilisation and reintegration (DDR) programme, especially in the context of the national amnesty programme which paved the way for the disarmament, demobilisation and reintegration of the ex-militants in the Niger Delta region. The study makes meaningful and timely contribution to local debates on the future of the Niger Delta after the amnesty programme, which ended officially in 2015. It offers insight to questions on post-amnesty Niger Delta raised by scholars and policy makers. Findings from the study will give students and scholars insight into perceptions communities have of ex-militants and Nigeria's DDR modelling. The way communities welcome people who were actively involved in armed conflict with the state is an addition to knowledge in the field of peace and conflict studies, international relations and strategic studies. This relates to the fact that acceptance of ex-militants by their communities is critical to the reintegration phase, which often lasts longer than the disarmament and demobilisation components.

\section{Methodology}

\section{Data collection:}

The study is both qualitative and quantitative. It used synthesised primary and secondary data. It involved comprehensive library research for the accumulation of all 
relevant information. The study also used a semi-structured questionnaire and in-depth interviews in selected communities in Akwa Ibom, Bayelsa, Delta and Rivers States to adequately give answers to the research questions already raised.

Instrumentation: The main focus of the instrument used in this study was on perception of people in the Niger Delta of the reintegration of ex-militants, the challenges and the prospects.

Interpretation of data: The data collected were analysed using Standard Package for Social Science (SPSS) 17. The study adopted a descriptive analytical approach in discussing perceptions people have of reintegration of ex-militants and the DDR modelling in Niger Delta, with the use of simple percentages. A notable methodological challenge was that some of the respondents were scared of having anything to do with the study until the author tried convincing them on their anonymity.

\section{Rationale for Disarmament, Demobilisation and Reintegration Modelling}

In terms of the context of disarmament, demobilisation and reintegration (DDR), Ibaba (2011, p. 243) avers that the Niger Delta conflict was triggered by several factors that are linked to the inhibition of goal attainment, centralised federalism and inequity in the distribution of oil arising from ethnicity-based political domination and neglect of the region's development; oil induced environmental degradation and the resultant occupational displacement; loss of income and increased poverty; corruption in governance and poor service delivery; and the neglect of corporate social responsibility by multinational oil companies and their refusal to pay or payment of inadequate compensation for damage to property caused by oil production activities. The frustrations arising from these triggered the armed conflict.

The United States Institute of Peace (USIP) promotes the universal view that disarming and demobilising ex-combatants is a highly visible process that can increase public confidence in the peace process. In the words of Hembruff (2010), the disarmament, demobilisation, and reintegration (DDR) process has been a staple of post-conflict projects implemented over the last decade, with over 60 DDR initiatives taking place since the early 1990s. Disarmament, demobilisation and reintegration programmes are designed to address some security challenges confronting a nation due to availability of small arms and light weapons in the wrong hands.

According to Muggah (2010), DDR operation has features, unique characteristics and particularities. In essence, disarmament, demobilisation and reintegration programmes are designed to create a society that is free of weapons of warfare, including small arms and light weapons, rocket propelled grenade and nuclear weapons. This will guarantee peace and stability in troubled states and make the world a safer place. Kemedi and Oko (2005, p.88) also posit that armed gangs or militias pose threat to the continued 
existence of society. This problem is one of the reasons why DDR programmes should be designed with the aim of enhancing public safety and addressing insecurity. In the words of Knight (2008), the DDR process is multidimensional and exceedingly complex, with political, military, security, humanitarian, and socioeconomic dimensions. Its primary goal is to address the post-conflict security challenge that stems from excombatants being left without livelihoods or support networks once wars come to an end and during the critical transition period from conflict to peace. DDR programmes seek to support ex-combatants' economic and social reintegration, so they can become stakeholders in peace and productive members of their communities. In this context, Nigeria's DDR was aimed at convincing militants (armed groups) to decommission illegally held weapons for stability to return.

Reintegration is a longer-term social and economic process with an open time frame designed to facilitate the assimilation of ex-militias (ex-combatants) in a way that allows them, and their families, to adapt to civilian life in communities that may not necessarily be ready to accept them. As noted by Ball and de Goor (2006), in most cases, this process involves the provision of cash or some form of compensation package in exchange for the commitment of ex-combatants not to return to conflict, providing ex-combatants with longer-term job or career training, initiating sustainable incomegeneration projects, repatriating refugees and displaced persons, and establishing a forum and process for truth and reconciliation. This stage of the DDR process is usually accompanied by efforts at rehabilitation of war-affected individuals and reconstruction of national infrastructure that was damaged as a result of the violence.

The Nigeria's DDR exercise has been described as the most generous, most comprehensive, as well as the most expensive amnesty or post-amnesty programme in the world. It is argued that the key issues that brought about the militancy have not been addressed (Amaize, 2012). The ex-militants who passed through the rehabilitation training at various camps in the Niger Delta were given some allowances and other forms of compensation package in exchange for their commitment not to return to conflict. What needs to be done is to investigate whether the situation in the Niger Delta has been transformed through the DDR programme or not, especially after rehabilitation training of most of the ex-militants has been carried out.

On the reintegration phase of the DDR programme, Nolasco and Munene (2012) contend that:

experience notes that the design of reintegration programmes should as matter of priority, include a clear understanding of the social, cultural, economic and political dynamics of both ex-combatants and the recipient communities. An understanding of these aspects should inform the planning of reintegration program and its sustainability (p. 9). 
This gives the impression that the sustainability of every DDR programme lies on the ability of stakeholders to capture the needs of ex-militias. Achievement of a safe and secure environment is critical in the DDR programme which would enable stakeholders to manage the activities of spoilers. However, Muggah, Maughan and Bugnion (2003) argue that reintegration does not always take place after demobilisation, while Nolasco and Munene (2012) advocate the paradigm of reintegration, demobilisation and disarmament (RDD) model that is more humane, peaceful and geared towards addressing security concerns instead of the usual disarmament, demobilisation and reintegration (DDR), stating that the whole programme design works backwards from the reintegration process because the effectiveness of the community reintegration process influences ex-combatants to want to disarm, as well as secures their long-term demobilisation, thereby creating sustainable social networks. Whichever approach adopted, the most important thing is that arms are removed from the wrong hands without the use of force because actualisation of positive peace remains the core objective of DDR programmes. Long- term peace would make the DDR to be described as successful.

Through the amnesty programme, the government successfully negotiated peace, with the agreement to implement the Niger Delta Regional Development Master Plan. Amnesty is from the Greek word amnestia, which means oblivion, complete obliteration or forgetting completely. According to Alabo-George (2012), the success of the national amnesty programme has translated to prosperity for the nation because Nigeria's crude oil production and export have climbed to a two-year high volume of about 2.6 million barrels per day. He sees the amnesty programme as a therapy that is rapidly healing the economy of the nation, while the region and its people only barely recover from the decades of environmental devastation. But one undisputable fact is that amnesty is necessary to help bring calm in any troubled region and resolve issues that have lingered for years.

Much literature has explored the nexus between DDR and peace agreement as regards confidence building, but with little emphasis on the ethical and security implications of failure to implement agreements signed by the parties involved in armed conflicts. Peace agreements are designed to convince militias to announce abandonment of armed struggle and dedicate themselves to promoting dialogue, negotiation and a peaceful solution of whatever conflict as well as to enhance confidence building. Griffiths and Barnes (2008, p.12) note that "political guarantees are often an integral aspect of peace agreements and involve political and practical support to assist implementation and assurances that external parties will use their influence to foster parties compliance with the terms agreed."

Undoubtedly, without the national amnesty programme, it would have been more difficult to even bring the militant groups out from the creeks or even realise the fact that their demands would not be met by resorting to armed struggle or violence. Successful 
DDR in the case of the Niger Delta would promote good business relationships, especially between host communities and multi-national oil companies. A proper rehabilitation programme is critical to successful reintegration to enable ex-militias to get used to civilian life because it differs from combatants' ways of life or life in the creeks.

Nolasco and Munene (2012) assert that successful cooperation and coordination among all actors guarantee successful disarmament, demobilisation and reintegration, albeit with proper planning. Effective use of resources and coherence on the ground in implementing the disarmament exercise has the potential of ensuring a successful DDR programme when stakeholders are committed to and focused on ensuring the successful completion of the security-oriented exercise. Mental demobilisation is an aspect of DDR that needs proper consideration by stakeholders to ensure that the achievements recorded through DDR programmes are sustained without being undermined by return to armed conflict. This is obvious because the minds of former fighters or militants remain critical to crime prevention, as disregarding them can motivate their involvement in threatening state security providers' law enforcement roles. According to Cunny (1991), "inability of governments to demobilise youths mentally is one of the precipitants of soaring crime rates and enduring political instability in former conflict theatres" (cited in Faleti 2005,p. 382). Proper consideration of psychological needs of former armed gangs or militias is a factor of stability in post-conflict societies considering the effects of an improper confidence-building process during DDR programme.

Nigeria is currently producing $2.68 \mathrm{~mm}$ bpd, short of a capacity of $3.7 \mathrm{~mm}$ barrels, according to the NNPC. Nigeria depends on oil exports for more than $95 \%$ of export income and $80 \%$ of all government revenue. Federal Government's control of oil revenue is resented by communities in the region and this has spawned unrest, including armed attacks on oil facilities and theft from pipelines (Bala-Gbogbo, 2012).

Some ex-militants were, however, disarmed and demobilised. For the demobilisation exercise, the Federal Government involved over 55 rehabilitation training partners and Non-governmental organisations in the country as well as experts from Nigeria, South Africa and the United States. The transformational or reorientation activities in the ex-militants' camps are tailored to extinguishing the perception of the ex-militants of violence or hostility and providing them a more powerful alternative of nonviolence (Africa Terrorism, 2012). Training partners were also contracted to provide training in 21 countries, including Ghana, Costa Rica, Malaysia, and South Africa.

\section{The Role of Perception in Reintegration: Theoretical Implication}

Perception refers to the way people regard or see things. Cataldi (2011) observes that perceptions frame the way we view the world and respond to it, particularly in situations of conflict. Perception, according to Berelson and Gary (1964), is a process by which information is selected, organised and interpreted by individuals. Devine, Hamilton and 
Ostrome (1995) see the perception of people and their actions by other people (social perception) as much more complex than psychological perception (the perception of objects). In social perception, people's actions are perceived in terms of some underlying motives, purpose, or desire.

The perception of cash for weapons is one of the challenges of DDR in the Niger Delta. Some ex-militants assume that surrendering their arms without financial benefits is not in their interest, as they are likely to be neglected after the DDR and end up not achieving their goal. The issue of perception is also applicable in the aspect of expecting that it is government's responsibility to pay them bimonthly allowances for disarming them. Perception has also been significant even as ex-militants try to reintegrate into their communities. Davidheiser and Nyiayaana (2011) contend that the disarmament was only partial, because the militants had held some arms back, highlighting their continued mistrust of the government and lack of confidence in its commitment to the peace-building agenda.

An important area that needs to be studied is the position and views of communities concerning reintegration of ex-militants and the DDR programme which has grave implications and prospects for peace in the region. Although Davidheiser and Nyiayaana (2011) note that the refusal of the Federal Government to further negotiate with the Movement for the Emancipation of Niger Delta (MEND) and frequent delays in the payment of bimonthly allowance of $\$ 65,000$ to the ex-militants reinforce and deepen perceptions of insecurity and distrust of the state by people in the region.

Hostility perception theory aptly explains what was observed when some former exmilitants who participated in the rehabilitation training threatened excluded ex-militants who agitated over their exclusion not to disrupt the programme. According to d'Estrée (2008), negative feelings and beliefs about the other party lead to negative interpretations of the other party's behaviour, reduce contact, make retaliation more acceptable, and result in reduced empathy for the other party (cited in Cataldi, 2011). Hostility perception theory states that the perception of the other as hostile to one or one's own group, identity, or culture tends to exacerbate conflict and conflict behaviour. Some of the ways this occurs include framing the lens through which actions by the other are viewed, perpetuating self-fulfilling cycles of negative and escalatory behaviour, and creating significant obstacles to problem-solving, relationship-building, and reconciliation (Catildi, 2011). The Federal Government sees some groups as potential threat to the future of Nigeria's DDR programme, which was scheduled to end in 2015. One of the ways of preventing the oil-related conflict occasioned by hostility perception of the other is giving adequate attention to people-centred development. Iruonagbe (2008) claims that, when people are given the opportunity to participate in decisionmaking and planning over issues that concern their livelihood, they are able to actualise their human potential, build self-confidence and lead lives of dignity and fulfilment. 
This self-actualisation will engage them in positive endeavours. People-centred development transforms and channels social conflict to prevent the undesired effects of conflict from reaching a critical point of tension that destabilises society and affects people (Nwobueze, 2015).

\section{Polls organised during the study}

Perceptions of the focus of the Niger Delta Amnesty Programme

\begin{tabular}{ll}
\hline Economic Empowerment: & $945=50.1 \%$ \\
\hline New Jobs: & $592=31.4 \%$ \\
Infrastructure: & $235=12.5 \%$ \\
Security: & $115=6.1 \%$ \\
Number of Voters: & 1887 \\
First Vote: & Monday, 24 May 2010, 08:46 \\
Last Vote: & Sunday, 18 November 2012, 06:09 \\
\hline
\end{tabular}

Source: Niger Delta Presidential Amnesty Office, Abuja

The essence of the polls was mainly to examine what the majority suggest should be the focus of government and implementing agencies. It was discovered that economic empowerment still remains the greatest need of the people, having 945 votes and over $50.1 \%$ out of 1887 votes as at 18 November, 2012. It is believed that when economic empowered is holistically carried out, new jobs, security and infrastructure would be achieved or the problems associated with security would abate.

\section{Field Results}

Table 1: Demographic characteristics of the respondents

\begin{tabular}{llcr}
\hline \multicolumn{1}{c}{ Age } & Frequency & Per cent \\
\hline \multirow{4}{*}{ Age } & $19-29$ & 96 & 62.8 \\
& $30-39$ & 33 & 21.6 \\
& $40-49$ & 10 & 6.5 \\
& 50 years and above & 14 & 9.2 \\
\hline \multirow{4}{*}{ Occupation } & Student & 72 & 47.1 \\
& Farmer & 32 & 20.9 \\
& public servant & 13 & 8.5 \\
& civil servant & 11 & 7.2 \\
& Business & 25 & 16.3 \\
\cline { 2 - 4 } & Total & 153 & 100.0 \\
\hline
\end{tabular}

The demographic profile of the 153 respondents interviewed in four states is shown in Table 1 . The respondents' age ranged from 19 to 100 years and had an average mean of 31.67 . The majority (62.8\%) of them belonged to $19-29$ years; $21.6 \%$ were within 
the age of 30-39; and 9.2\% were within 50 years and above; while those $40-49$ years had the lowest percentage of 6.5 . Overall $7.2 \%$ and $8.5 \%$ of the sampled population reported that they were civil and public servants, respectively; $20.9 \%$ were farmers, $16.3 \%$ were into business; and $47.1 \%$ were students.

Table 2: Perceptions of people in the Niger Delta communities of the reintegration of ex-militants in their communities

\begin{tabular}{|c|c|c|}
\hline People's perception & Yes & No \\
\hline Link between militancy and unemployment/poverty & $148(96.7)$ & $5(3.3)$ \\
\hline Presence of ex-militants in the community as a problem & $31(20.3)$ & $122(79.7)$ \\
\hline $\begin{array}{l}\text { Militants overseas vocational training as the best reintegration } \\
\text { strategy in managing militancy }\end{array}$ & $120(78.4)$ & $33(21.6)$ \\
\hline $\begin{array}{l}\text { Federal Government did the right thing by giving ex-militants } \\
\text { that passed through the non-violence/rehabilitation training } \\
\text { some allowances /compensation package in exchange for } \\
\text { their commitment not to return to conflict was right. }\end{array}$ & $141(92.2)$ & $12(7.8)$ \\
\hline Ex-militants are still security risks to their communities. & $36(23.5)$ & $117(76.5)$ \\
\hline Belief in the sustainability of peace in the Niger Delta & $137(89.5)$ & $16(10.5)$ \\
\hline
\end{tabular}

There have been different perceptions of the reintegration of ex-militants into their communities. Table 2 shows that the majority (96.7\%) of the sampled population believed there is a strong relationship between militancy and unemployment/poverty; while 3.3\% had a contrary opinion. This finding corresponds with United Nations General Assembly (2007), which maintains that young people with limited education and few employment opportunities often provide fertile recruiting ground for parties to a conflict. Also, $79.7 \%$ of the respondents reported that having ex-militants in their communities poses no danger, as against the $20.3 \%$ who believed that the integration of ex-militants into their communities is a problem.

Evaluating the amnesty programmes organised for the ex-militants, $78.4 \%$ of the respondents were convinced that sending some repentant militants abroad for vocational training was the best reintegration strategy in managing militancy. However, this opinion was not shared by $21.6 \%$ of the respondents, who preferred other re-integration strategies.

There was a significant difference in the number of respondents who agreed that the Federal Government did the right thing by giving the ex-militants that passed through the non-violence/rehabilitation training some allowances /compensation package in exchange for their commitment not to return to conflict was right $(92.2 \%)$ and those who felt the Federal Government's engagement of the ex-militants in rehabilitation process was a misplaced priority $(7.8 \%)$.

With regard to the opinions of the respondents on the security risk involved in having ex-militants in communities, $76.5 \%$ of the respondents argued that such ex-militants 
pose no threat to their communities on the event of their being re-integrated. On the contrary, about $23.5 \%$ argued that the presence of ex-militants in their communities is a security threat.

Table 3: Prospects of the DDR programme in oil-producing communities

\begin{tabular}{lcc}
\hline \multicolumn{1}{c}{ Rating } & Frequency & Per cent \\
\hline Excellent & 2 & 1.3 \\
Very good & 17 & 11.1 \\
Good & 67 & 43.8 \\
Fair & 63 & 41.2 \\
Poor & 4 & 2.6 \\
\hline Total & 153 & 100.0 \\
\hline
\end{tabular}

There have been mixed feeling on the prospect of the DDR programmes in oil-producing communities in the Niger Delta. Table 3 the rating of $1.3 \%$ (excellent), $11.1 \%$ (very good), $43.8 \%$ (good), $41.2 \%$ (fair) and $2.6 \%$ (poor) indicates that the DDR programmes in the oil-producing communities in the Niger Delta have been successful. This finding is based on the success of the disarmament phase of the DDR programme. The xxmilitants were reintegrated into their various communities through vocational skills training, formal education or entrepreneurship skills acquisition either in Nigeria or abroad after their rehabilitation programme.

Despite the successes recorded during the DDR programme, few respondents still doubt its sustainability. Some ex-militants find it difficult to adjust to communal life, they constitute nuisance and tend to be aggressive and engage in deviant activities. An interview with Mr. EV confirmed that the ex-militants are already involved in criminal cases owing to their negative attitude. Inadequate attention, love and care become stressors that can make ex-militants take to deviant risk behaviours which, most times, disrupt communal life. Unless there is proper programme coordination, proper remuneration of ex-militants, adequate funding of reintegration programmes and complete de-traumatisation of ex-militants, the success cases may be temporal.

The DDR programme was designed in such a way that will aid capacity development and expose the ex-militants to self-sufficiency, vocation and skill acquisition and formal education. However, the DDR programme has not been without serious challenges that have tried to disrupt the execution of the programme.

The challenges faced by the ex-militants and the organisers of the re-integration programme are presented in Table 4. The majority (49\%) of the respondents reported that non-payment of ex-militants compensations and allowances was a major challenge. The allowances included housing allowances, feeding allowances and transportation allowances, and start-off fund for the establishment of small and medium enterprises (SMEs) to facilitate the re-integration process. 
Table 4: Challenges facing successful reintegration of ex-militants

\begin{tabular}{|c|c|c|c|}
\hline & Challenges & Frequency & Percentage \\
\hline \multirow{5}{*}{$\begin{array}{l}\text { Challenges faced } \\
\text { by the ex-militants }\end{array}$} & Stigmatization & 27 & 17.6 \\
\hline & non-payment of compensations and allowances & 75 & 49.0 \\
\hline & inadequate training facilities and funding & 45 & 29.4 \\
\hline & lack of trust and non-compliance & 6 & 3.9 \\
\hline & Total & 153 & 100.0 \\
\hline \multirow{5}{*}{$\begin{array}{l}\text { Challenges faced } \\
\text { by the organisers } \\
\text { of the re-integration } \\
\text { programme }\end{array}$} & limited funding & 19 & 12.4 \\
\hline & Politicisation & 54 & 35.3 \\
\hline & lack of qualified personnel & 33 & 21.6 \\
\hline & unwillingness of the ex-militants to undergo re-integration & 47 & 30.7 \\
\hline & Total & 153 & 100.0 \\
\hline
\end{tabular}

About $29.4 \%$ of the respondents noted that inadequate training facilities and funding were challenges during the re-integration programme, in addition to stigmatisation (17.6\%) and lack of trust (3.9\%). This is in tandem with various reports that infrastructural facilities were not adequate during re-integration, resulting in most ex-militants leaving their camps in Benin, Yenagoa and Aluu in Port Harcourt. On the part of the organisers of the re-integration programme, $35.3 \%$ agreed that the re-integration programme was hijacked by top politicians who had vested interest in the programme. That affected the way and manner the programme was executed. About $30.7 \%$ of the respondents agreed that unwillingness of the ex-militants to undergo re-integration was a challenge encountered during the re-integration process; $21.6 \%$ reported that lack of personnel was a challenge; and $12.4 \%$ submitted that limited funding hampered the re-integration programme.

So far, the DDR programme has recorded some level of success three years into the programme. However, the concern among oil companies is that there is a risk of a slide back to violence if stakeholders do not seize the opportunity presented by the current relative calm to begin to build a better and fairer future for the Niger delta. Oil production is currently below the pre-militancy levels, which seems to be worsened by the massive organised oil theft business and the criminality and corruption that are attached to it. At least, $150,000 \mathrm{bpd}$ of oil is lost to theft, resulting in increased production costs, reduced revenue and major environmental impacts. Increasing crude theft along Shell's Nembe Creek trunkline threatens daily exports of 140,000 barrels; and the company has recorded over 250 incidents of theft and sabotage in its onshore operations since January 2010 (Bala-Gbogbo, 2012).

Mitee (2012) attributes the current challenges of Niger DDR to government's failure to properly evaluate and positively respond to the challenges facing the Niger Delta, which has resulted in an overwhelming community feeling of anger and frustration 
that the irreplaceable revenue from the resources of their land is exploited and used for the development of other areas whilst they live in pristine conditions, with a pervasive regime of poverty, an increasing army of unemployed youths creating a ready pool of recruitable youths for politics.

The DDR programme was so challenging that most of the officers that coordinated the disarmament phase had to embark on medical check-up abroad at their own expense at the end of the exercise. It was also described as frustrating owing to insufficient resources and funds and things being done at cross-purposes. Plans for the amnesty programme were inadequate and ex-militants getting jobs even after going for training is problematic (Amaize, 2012). It was discovered that about $45 \%$ of the ex-agitators currently enrolled on the Amnesty Programme cannot read or write, while provisions are now made for them to participate in remedial education before their placement in skills acquisition centres within and outside Nigeria (Africa Terrorism, 2012).

The leadership of Niger Liberation Force (NDLF), an unrepentant militant group in the Niger Delta, demanded A1billion naira from the Federal Government as compensation for the alleged extra-judicial murder of its leader, General John Togo, aerial bombing and killing of innocent citizens of Ayakoromor community by soldiers of the Joint Task Force. The demand was due to the alleged Federal Government's payment of $\$ 100 \mathrm{~m}$ compensation to the family of the slain leader of the Islamist group, Boko Haram, Mohammed Yusuf, who was reportedly killed by the police in custody. The group noted thus:

We, therefore, consider this as a slap on our face and urge the Federal Government to make immediate compensation through our legal team before or not later than 21 June, 2012, or else, NDLF will be forced to go back to the creeks for action. The leadership has directed all NDLF soldiers and intending recruits to get ready for action, if the government ignores our demand (Oyadongha \& Ahon, 2012, p. 1).

What such demand means is that agitations are not yet over in the Niger Delta, as more groups either agitate over exclusion from the DDR programme or for payment of the $\$ 65,000$ allowance as beneficiaries.

Findings from this study also showed that the Federal Government's intervention policies and structures towards tackling the problems of unemployment and poverty among youths are inadequate, poorly-packaged and are more of palliatives. In the case of Delta State, the agitations by the Urhobo and Itsekiri ethnic nationalities revealed that there were serious lapses at the planning stage of the DDR which would have been designed in such a way that that the programme would accommodate those that were actively involved in militancy and surrendered their arms to the Presidential Amnesty Committee before the deadline of October 2009. This greatly eroded the confidence people had in government. 
In terms of carrying out reintegration with less emphasis on development, it must be emphasised that development transcends training a few troublesome youths and paying them allowances. Most people always believe that government is not always straightforward in handling issues of development, especially in developing the oil-rich region. There is no gainsaying the fact that, in spite of the efforts made in the past to develop the Niger Delta, the region is still bedevilled by massive environmental degradation and huge infrastructure deficit. A major contributory factor to this state of affairs is lack of coordination and synergy among the stakeholders that are saddled with the responsibility of developing the region (Soriwei, 2012). This also explains why the East West Road, which links Delta, Bayelsa, Rivers and Akwa Ibom States, still remains in a bad condition. Such development challenges are counterproductive to the ongoing DDR programme which was scheduled to end in 2015. However, the government is still addressing the unfinished issues arising from the reintegration phase of the DDR.

One of the challenging aspects of Nigeria's DDR programme is the exclusion of some eligible ex-militants who actively participated in the armed struggle but were not included in the rehabilitation training organised by Federal Government's Amnesty Office. Mr. Kingsley Kuku (former Presidential Adviser on the Niger Delta) accepted the fact that they were excluded due to documentation problems. This would make some communities and affected ex-militants to see the government as not being sincere in implementing the components of the amnesty even after disarming them by convincing them to surrender their arms unconditionally. The implication is the possibility of resurgence of agitations and counter-agitations by such groups so as to be included; government's failure to do that would portend grave threat for peace and human security in the oil-rich region.

\section{Concluding Thoughts}

This study has examined the perceptions of Nigeria's DDR programme which commenced in 2009. So far, the programme has been helpful in addressing the problem of instability occasioned by the activities of oil companies and underdevelopment of the region. According to the Amnesty Office, in May 2011, a closure was achieved in the disarmament phase of the Amnesty Programme when the Amnesty Office, in collaboration with the 82 Division of the Nigerian Army, publicly destroyed the arms and ammunition submitted to the Federal Government by the Niger Delta ex-agitators who accepted the offer of amnesty in 2009. This exercise took place in Lokpanta, a boundary town in Enugu State. The Amnesty Office gave the total number of people enlisted in the Presidential Amnesty Programme as 26,358. Contrary to Mr Kingsley Kuku's assertion that some ex-agitators were not able to return to their communities to lead a normal civil life because of perceived fear of stigmatisation and exclusion, it was observed that the communities did not have much problem living with ex-militants. 
It is obvious from this study that most of the communities did not actually have problems with ex-militants but were mainly interested in development of their communities. From the foregoing, just like most people in the Niger Delta, the pioneer coordinator of the Presidential Amnesty Programme for Niger-Delta ex-militants and the Ovie (King) of Umiaghwa- Abraka Kingdom in Delta State, Air Vice Marshall Ararile (rtd.), argued that creating jobs for the unemployed youths is the most reliable way to mitigate youth restiveness (Amaize, 2012). Robust infrastructural transformation and human resource development would offer timely solution to the question of what should be the next action after the DDR programme in the Niger Delta. The resurgence of militant groups since 2015 is a pointer to the fact that urgent steps must be taken to prioritise youth and people-centred development and conflict transformation.

The DDR programme should be all-inclusive rather than implementing a selective approach that would end up being counterproductive. Sincerity of government agencies and acceptance of ex-militants by their communities would improve their confidence and deter them from returning to the creeks. The role of the Federal Government is to peacefully discourage any form of rearmament. It must, however, be emphasised that the Niger Delta peace is not a product of any form of dialogue or peace agreement, as earlier stated by , Mr. Kingsley Kuku, though he was right in asserting that it was a product of patriotism and tenacity. There was no formal peace agreement signed before the commencement of the DDR as seen in most countries where DDR is carried out, but it remains to be seen from the Niger Delta experience whether proclamation of amnesty works better than peace agreements in post-conflict societies.

Although the perception of communities about reintegration of ex-militants is generally positive, the fact is that all they want is government's sincerity as far as people-centred development in concerned. This approach has conflict management value which would translate to sustainable development. Discouraging the resurgence of youth restiveness demands timely management of the conflicts that are motivated by grievances and lack of equity in the distribution of resources in the Niger Delta region.

\section{References}

1. Africa Terrorism. (2012, October 5-7). The Presidential Amnesty Programme in Nigeria, Maiden Edition.

2. Alabo-George, R. (2012). Thirteenth Year of the 13 per cent: Amnesty and amnestia. The Punch, p. 16.

3. Amaize, E. (2012). How some forces tried to scuttle amnesty for ex-militants - Ararile, Delta monarch. Vanguard. Retrieved from http://www.vanguardngr.com/2012/08/ how-some-forces-tried-to-scuttle-amnesty-for-ex-militants-ararile-delta-monarch/.

4. Ashkenazi, M. (2013). Forces of Order and Disorder: Security Providers and Conflict Management. In V. C. Franke and R. H. Dorff (Eds), Conflict Management and Peacebuild- 
ing: Pillars of a New American Grand Strategy (pp. 271-294). PA: United States Army War College Press.

5. Bala-Gbogbo, E. (2012, March 5). Nigerian Delta unrest cuts oil output;. Gas and Oil News. Retrieved from http://www.gasandoil.com/news/africa/7e57abc3dec4b42186 945b211a8baf7e.

6. Ball, N., \& de Goor, L. V. (2006). Disarmament, Demobilization and Reintegration: Mapping Issues, Dilemmas and Guiding Principles. Hague: The Netherlands Institute of International Relations.

7. Berelson, B. \& Gary, A. S. (1964). Human Behaviour: An Inventrory of Scientific Finding. New York: Harcourt Brace.

8. Cataldi, R. (2011). Clash of Perceptions: Hostility Perception and the US-Muslim World Relationship. Journal of Peace, Conflict \& Development, 18, 27-46.

9. Danjibo, N. D., \& Okolie-Osemene, J. (2018). Religious Movements and Lethal Violence in Nigeria: Patterns and Evolution. Africology: The Journal of Pan African Studies, 11(4), 177-185.

10. Davidheiser, M., \& Nyiayaana, K. (2011). Demobilisation or Remobilisation? The Amnesty Program and the Search for Peace in the Niger Delta. African Security 4(1), 44-64.

11. d'Estrée, P. (2008). Dynamics. In S. Cheldelin, D. Druckman and L. Fast (Eds.), Conflict ( $2^{\text {nd }}$ edition) (pp. 71-92). London: Continuum.

12. Devine, P., Hamilton, D. L., \& Ostrome, T. M. (1995). Social Cognition: Impact of Social Psychology. New York: Academic Press.

13. Donais, T. (2017). Engaging Non-state Security Providers: Whither the Rule of Law?. Stability: International Journal of Security \& Development, 6(1), 1-13.

14. Faleti, S. A. (2005). Termination of Protracted Social Conflicts in Africa. In I. O. Albert (Ed.), Perspectives on Peace and Conflict in Africa (pp. 370-390). Ibadan: John Archers (Publishers).

15. Griffiths, A. \& Barnes, C. (2008). Incentives, Sanctions and Conditionality in Peacemaking. In A. Griffiths and C. Barnes (Eds.), Powers of Persuasion (pp. 4-23). London: Conciliation Resources.

16. Guéret, T. (2017, April 13). Niger and the Fight Against Violent Extremism in the Sahel. RUSI. Retrieved from https://rusi.org/commentary/niger-and-fight-against-violentextremism-sahel.

17. Gupte, J. (2017). These Streets are Ours: Mumbai's Urban form and Security in the Vernacular. Peacebuilding, 5(2), 203-217. DOI: 10.1080/21647259.2016.1277022.

18. Hembruff, J. (2010). Innovations in Disarmament, Demobilisation, and Reintegration Policy and Research. Waterloo: Centre for International Governance Innovation.

19. Hove, M., Ngwerume, E. T. \& Muchemwa, C. (2013). The Urban Crisis in Sub-Saharan Africa. Stability, 2(1), 1-14. DOI: http://dx.doi.org/10.5334/sta.ap.

20. Ibaba, S. I. (2011). Amnesty and Peace-Building in the Niger Delta: Addressing the Frustration-Aggression Trap. Africana: The Niger Delta, 5(1), 238-271. 
21. Iruonagbe, T. C. (2008). The Niger Delta Crisis: Challenges and Prospects for Peace and Stability. International Conference on the Nigerian State Oil Industry and the Niger Delta, Conference Proceedings (pp. 633-642). Port-Harcourt: Havey Publications Company.

22. Kemedi, V. D., \& Oko, M. (2005). Urban Youth. In Academic Associates Peaceworks (Ed.), Niger Delta Peace and Security Strategy Working Papers (pp. 88-100). Port Harcourt: International Centre for Reconciliation.

23. Knight, A. W. (2008). Disarmament, Demobilization, and Reintegration and Post-Conflict Peacebuilding in Africa: An Overview. African Security, 1(1), 24-52.

24. Mitee, L. (2012, July 9). Issues and Challenges of the Niger Delta Amnesty Programme: An Insider Perspective. A Paper Presented as Occasional Guest Lecturer at the Society for Peace Studies and Practice, Institute of African Studies, University of Ibadan, Nigeria.

25. Muggah, R., Maughan, P., \& Bugnion, C. (2013). The Long Shadow of War: Prospects for Disarmament, Demobilisation and Reintegration in the Republic of Congo. Brussels, New York and Washington: A Joint Evaluation for the European Commission, UNDP and MDRP Secretariat.

26. Muggah, R. (2010). Innovations in Disarmament, Demobilization and Reintegration Policy and Research: Reflections on the Last Decade. NUPI Working Paper 774. Oslo: Norwegian Institute of International Affairs.

27. Musari, A. (2012, March 27). Imperatives of tackling human capital, infrastructure deficit in Niger Delta. The Guardian, p. 3.

28. Nolasco, L. K. \& Munene, M. (2012). Armed Pastoralists in North Rift Valley - a shift towards reintegration, demobilisation and disarmament. Horn of Africa Bulletin, 1, 5-9.

29. Nwafor, W. E. (2011). Development Administration and Political Economy in Nigeria. Aba: Cheedal Global Prints Ltd.

30. Nwobueze, C. C. (2015). Youth-focused Human Development and Conflict Transformation in the Niger Delta, Nigeria. Ph.D Thesis presented at the Institute of African Studies, University of Ibadan, Nigeria.

31. Nwobueze, C. C., \& Okolie-Osemene, J. (2017). Outlaw Security Providers and Arms Proliferation in Rivers State: The Security Collaboration Conundrum. Journal of Sustainable Development in Africa, 19(3), 117-131.

32. Odera, O., Scott, A., \& Gow, J. (2018). Community Perceptions of Nigerian Oil Companies Commitment to Social and Environmental Concerns. Journal of Global Responsibility, 9(1), 73-95.

33. Okolie-Osemene J., \& Okolie-Osemene, R. I. (2017). The Challenges and Prospects of Security Sector Manoeuvrability over Terrorism in Somalia. In S. Romaniuk, F. Grice, D. Irrera and S. Webb (Eds.), The Palgrave Handbook of Global Counterterrorism Policy (pp. 925-943). London: Palgrave Macmillan.

34. Oyadongha, S., \& Ahon, F. (2012, June 10). Militants demand N1bn reparation, give Jonathan June 21 deadline. Vanguard. Retrieved from http://www.vanguardngr. com/2012/06/militants-demand-n1bn-reparation-give-jonathan-june-21-deadline/. 
35. Soriwei, F. (2012, November 3). Niger Delta Ministry: Postponing real Development. The Punch, p. 45.

36. UN. (2007). Final Report on the Second International Conference on DDR and Stability in Africa, Peace, Stability and Development. New York: United Nations. 